\title{
Enhancing Self-Regulation Skills through Group Investigation Integrated with Think Talk Write
}

\section{Lina Listiana}

P Department of Biology Education, Muhammadiyah University of Surabaya, East Java, Indonesia, linalistiana521@gmail.com

\section{Raharjo}

Universitas Negeri Surabaya, Jalan Rektorat Unesa, East Java, Indonesia, raharjoraharjo@gmail.com

\author{
A. Saepul Hamdani \\ Universitas Islam Negeri Sunan Ampel, East Java, Indonesia, \\ asepthea310765@gmail.com
}

This study aims to (1) determine the difference between the improvement in
students' self-regulation skills before and after the implementation of the GITTW
learning strategy, and (2) describe students' perception of the skills of self-
regulation before and after the implementation of the GITTW learning strategy.
This is pre-experimental research using a one-group pre-test-post-test design. The
population was made up entirely of students in their sixth semester at the Biology
Education department who programmed the Physiology Anatomy of Human Body
course in the $2017 / 2018$ academic year in the Teacher Training and Education
Faculty at University of Muhammadiyah Surabaya, Indonesia. The samples
comprised of 20 students from one class. The data of students' self-regulation
skills were obtained from the score of an essay test and inventory method. The data
were analysed using descriptive and inferential statistics with the N-gain test. The
results showed that the students' self-regulation skills improved after the
implementation of the GITTW learning strategy. This can be seen from the average
pre-test score of 36.2 , the post-test score of 74 , the average gain of 37.8 and the
average N-gain of 0.60 included in the medium category. The average inventory
self-regulation skills score before the implementation of the GITTW learning
strategy reached $76.57 \%$, including the strong category, and after it reached $80 \%$,
including the very strong category.

Keywords: education, learning strategy, self-regulation skills, student, group investigation, think talk write 


\section{INTRODUCTION}

Student-centered learning places students as "subjects" not as "objects" of learning. Students are given opportunities to regulate or direct their learning (Bannert, et al., 2015). With such a learning process, students are expected to have the authority to regulate and determine their learning success. The ability to regulate and determine their own learning success is known as self-regulation skills. Self-regulation in learning is not a mental ability or academic performance skills, but rather a process of directing oneself to transform mental abilities into academic skills. Self-regulation refers to the management of thoughts, emotions, and behavior to achieve goals (Zimmermann, 2002).

Self-regulation skills are needed in this 21 st century to overcome life's challenges. This skill can be obtained through learning biology. The process of learning biology is related to the problems of daily life, thus encouraging the understanding and solving of problems discussed with current and future biological developments. Therefore, selfplanning is needed to be very necessary and need to be empowered during biology learning.

It is important for students to be trained in self-regulation because students who have good self-regulation skills will achieve well in their learning. The research results of Chen (2002) show that self-regulation has a positive correlation with learning motivation. Other research results find that students who have high self-regulation skills tend to learn better, and are able to monitor, evaluate and manage their learning effectively, to effectively use time in completing their tasks, to efficiently manage learning and time, and to obtain high scores in science (Psycharis \& Kallia, 2017). Selfregulation is the ability to regulate oneself in constructive and active learning so that students design their own learning strategies, and activate their metacognition, motivation and behavior aspects in order to achieve satisfactory learning results.

It is essential to experience and empower students in self-regulation skills during learning activities. However, classroom learning is still lacking in empowering students' self-regulation skills. Based on the results of an observation of the Physiology Anatomy of Human Body course, it was found that students would be motivated to learn and prepare for learning if they had previously been given assignments or homework. Most students in one class learned without any preparation. Moreover, it was also found that students' learning results on the Physiology Anatomy of Human Body course decreased with a relatively low average score, which was a grade C (54-65) (Listiana and Suharti, 2017). This is assumed to be correlated with students' self-regulation skills.

Self-regulation development is important for students to train because students who have good self-regulation skills will achieve well in their learning. The research results of Chen (2002) show that self-regulation has a positive correlation with learning motivation. Other research results find that students who have high self-regulation skills tend to learn better, and are able to monitor, evaluate and manage their learning effectively, to effectively use time in completing their tasks, to efficiently manage learning and time, and to obtain high scores in science (Psycharis \& Kallia, 2017). Selfregulation is the ability to regulate oneself in constructive and active learning so that 
students design their own learning strategies, and activate their metacognition, motivation and behavior aspects in order to achieve satisfactory learning results.

The application of an appropriate learning strategy is one of the influential factors in empowering students with self-regulation skills. This is in line with the results of Sungur and Tekkaya (2006), which reported that there is an increase in self-regulation ability after the implementation of the Problem Base Instruction learning strategy. Bahri \& Corebima (2016) stated that contribution of learning motivation and metacognitive skills simultaneously on cognitive learning outcomes within different strategy as integrated PBL-RQA, PBL, RQA, and conventional learning strategies was very high. According to Bahri and Idris (2018), self-regulated learners can be empowered or trained through certain strategies or efforts. Thus, empowering students with self-regulation skills can be achieved through planning and adapting to the use of learning strategies. It is a challenge for educators to be able to design and implement a constructive and innovative learning strategies.

One strategy that is considered appropriate to empower students' self-regulation skills is the GITTW (Group Investigation Integrated Think Talk Write) strategy. GITTW Strategy is one of the models of cooperative learning, with its syntax identifies topics and organizes groups, planning tasks, investigating, analyzing, presenting and evaluating the results, by integrating think, talk and write at each stage/syntax (Modified by Listiana, 2016 from Sharan \& Sharan, 1992 and Huinker \& Laughlin, 1996). Each stage of the GITTW strategy trains students to improve self-regulation in determining learning strategies and task planning. University students are trained independently in investigating and analyzing with a view to solving problems (DePorter, 1992; Sharan \& Sharan, 1992; Slavin, 2008).

GI strategy and TTW strategy are a form of cooperative learning that demands cooperative training in completing tasks. In addition, the students learn to carry out selfassessment and self-control, which is part of self-regulation (Slavin, 2008). In the GI Strategy in GITTW, students are prepared to study in groups, Mitchell et al., (2008) formulate questions or determine problems, choose procedures for monitoring and assessment. Akcay \& Doymus (2012) reported that the group determines the topic of questions in a particular unit and makes an investigation plan, during the discussion group members use science books to identify problems. Tsoi, Goh \& Chia (2004) reported that in GI students are motivated to play an active role in determining what and how to be learned. In the final stage, students with their groups draw conclusions, then set the strategy for presenting the results and evaluating the group's results. This shows the habits of students in conducting self-assessment and self-control of their learning outcomes. This helps students become self-regulated learners.

The TTW strategy in GITTW, the thinking stage helps empower students' thinking abilities, "Think" is needed when students identify problems, determine strategies, and make problem-solving plans. In the talk and write stages, it can be seen in the presentation and discussion activities of the problem-solving results. According to Rivard \& Straw (1999), talk is important during discussions to share, clarify, and distribute ideas and ask questions, hypothesize, explain, and formulate ideas together. 
The Write phase is also important to perfect and consolidate these new ideas with prior knowledge. It can be expected that the GITTW strategy helps develop students' independent learning abilities.

\section{Statement of Problems}

The problem of this research is how to improve students' self-regulation skills before and after the implementation of the GITTW strategy in learning biology. This study was also conducted to evaluate the students' perceptions regarding self-regulation skills after using the GITTW strategy. This research is important to inform that the GITTW strategy can be used to develop and train students' self-regulation skills during the Biology course in the classroom. The implementation of the GITTW strategy in other courses in Biology can maximize its potential in empowering self-regulation skills.

\section{THEORETICAL BACKGROUND}

\section{Self-Regulation Skills}

Self-regulation is the ability to regulate oneself in active learning so that students design their own learning strategies and empower their metacognition to achieve satisfying learning results. According to Zimmerman (2002), self-regulation refers to students' ability to regulate their thoughts, feelings and behaviors, which are oriented towards achieving learning goals. Zimmerman (1989) also believes that students who perform self-regulated learning are those who are metacognitively, motivationally and behaviorally active participants in the learning process. In line with Bandura (1993), self-regulation involves three important psychological functions in learning, namely cognitive (for example, learning strategies), motivation (for example, self-efficacy, task values) and metacognition (for example, self-monitoring and self-reflection).

Metacognition is a person's knowledge of his cognitive processes. Metacognition is related to students' ability to monitor, plan, organize and evaluate their own learning (Boekearts, 1996; Zimmerman, 1989). The term "metacognition" is closely related to self-regulation, which refers to the ability to think about the thinking process and the ability to regulate and control cognitive processes. Pintrich (2000) asserts that the metacognitive component is that students monitor their learning progress as well as their thinking in completing tasks. This is in line with Livingston (1997), who states that metacognition refers to high-order thinking skills, which include active control over cognitive processes in learning. Activities such as planning how to approach a given task, controlling understanding and evaluating the progress of a particular task are natural metacognition. Self-regulation plays an important role in achieving learning objectives, especially in some subjects that are considered to be difficult and require high analysis: for example, Physiology Anatomy of the Human Body.

Another component of self-regulation is behavior. Behavior in self-regulation means that students make a decision and performan action to optimize their learning environment (Zimmerman, 1990). To empower students' behavior in making decisions and performing actions in learning, it is essential to emphasize he learning process. Cooperative learning, as stated by Slavin (1994), is an innovative learning that 
emphasizes the nature of social learning. It is also one of the characteristics of the constructivism learning approach. Self-regulation skills which analyzed in this research was (1) self-regulation skills which measured by essay test which is integrated with concept understanding and consist of sevent question about Human Anatomy and Physiology, and (2) self-regulation skills measured using Metacognitive Skills Inventory (MSI) which is adapted from MAI (Schraw \& Dennison, 1994) dan SEMLI-S (Thomas, $\mathrm{dkk}, 2008)$. The inventories consist of 34 items which is divided into skills for plannig, monitoring, evaluation, and revising.

\section{GITTW (Group Investigation Integrated with Think Talk Write) Learning Strategy}

GITTW is a Group Investigation (GI) learning strategy combined with the Think Talk Write (TTW) strategy. This combination occurs by integrating the stages of the TTW learning strategy at each stage of the GI syntax. With all the weaknesses and strengths of the syntax of both learning strategies, they become complementary. This strategy, which is then known as GITTW, is packed in cooperative model learning. The syntax of the GITTW strategy is: (1) identifying topics, grouping and determining subtopics (by integrating Think and Write); (2) planning the tasks that will be studied and compiling the results of the discussion (integrated with Think, Talk and Write); (3) investigating, observing, collecting and writing information (by integrating Think and Write); (4) analyzing, discussing and synthesizing information (by integrating Think, Talk and Write); (5) presenting the final results and conducting a class discussion (by integrating Think and Talk); and (6) evaluating, reflecting and concluding (by integrating Think, Talk and Write)

Through the first GITTW syntax, students choose the topics to be discussed and organize the group. This activity trains the decision-making skills independently of group agreements, and at this stage thinking and writing skills are also trained. The second syntax is the planning of tasks that will be studied and compiling the results of the discussion. In this part, each group discusses, organizes and plans to share tasks with group members to solve problems. Here students practice thinking and writing it down and then share it with other groups. The third syntax incorporates investigating, observing, collecting and writing information; this stage needs a high level of thinking and a good style of writing. Here, the students are trained independently to conduct their own investigation by planning the learning strategies to obtain information. The fourth syntax of the GITTW is analyzing, discussing and synthesizing information. At this stage student learn actively in their groups, and regulate and control their way of learning to produce conclusions. The fifth syntax is to present the final results and conduct class discussions, at this stage to train students to plan and arrange the presentation method, determining strategies to answer questions. Finally, the sixth syntax is evaluating, reflecting and concluding; this stage trains students to assess the work of their own groups and other groups, and students are also trained to reflect and control what has been done and how the feedback improves the learning outcomes. The implementation of the GITTW strategy in lectures will train and familiarize the students in learning independently. 
Based on the analysis above, in the GITTW syntax students are trained to set their own way of learning, determine learning strategies, learn actively, and conduct evaluations by controlling and assessing learning outcomes. The students begin to learn by determining their own topics, planning ways of working, collecting information by themselves, and presenting and evaluating their own work. All these activities show an independent learning process; this supports the empowerment of self-regulation skills that encourage students to be independent learners. Along with Woolfolk's opinion (1987), that independent learning habits will shape students into self-regulated learners. Thus, the GITTW strategy has great potential to empower self-regulation skills.

Some of the previous researches on the GITTW strategy indicate several advantages. Listiana's (2013) GI (Group Investigation) strategy combined with TTW (Think, Talk and Write) is an innovative learning that has the potential to empower thinking skills. Listiana et al. (2016) reveal that the GITTW learning strategy has the greatest effect on empowering metacognitive skills. In addition, Listiana et al. (2015) demonstrate a contribution of metacognitive skills to cognitive learning outcomes through the implementation of GITTW strategies. The GITTW strategy is a model of cooperative learning that builds learning communities by training group learning, and high-level thinking (Cen, et al., 2016). Learning in groups is a method to encourage maximum involvement of students in learning. The GI and TTW strategies at GITTW both develop independent learning so that students are responsible for their own learning in completing difficult tasks, and managing and controlling their learning.

The research results on the GI (Group Investigation) strategy and the TTW (Think Talk Write) strategy reveal many advantages. The research by Mite \& Corebima (2017) reports that GI can improve metacognitive skills and concept gaining. Zubaidah, et al. (2018) reveal that the implementation of the cooperative GI model could improve students' thinking skills and scientific attitudes. This is in accordance with Sihombing, et al. (2018) and Susantini, et al. (2018) that the cooperative GI model involves highorder thinking skills in completing tasks. The research results on TTW, Ansari (2004) and Hosseini, et al. (2018) on mathematics learning, Ozsoy \& Ataman (2009) on biology learning and Zulkarnaini (2011) on Indonesian language learning reported that the TTW learning strategy improved students' concept gaining and communication, problem-solving skills, learning activities and critical thinking skills.

The GITTW learning strategy is an innovative learning strategy that has the potential to empower thinking skills (Listiana, 2013). Some results from research conducted by Listiana et al. (2016) reveal that the GITTW learning strategy has the greatest effect on the empowerment of metacognitive skills. Listiana et al. (2015) showed that metacognitive skills made a contribution toward cognitive learning results through the implementation of the GITTW strategy. The implementation of the GITTW learning strategy is also adjusted to the indicators of self-regulation skills, namely rehearsal, which is the effort to remember the learning material by doing multiple exercises to easily master the learning material. Elaboration is using our own words for completing the tasks/problems set by the lecturer, organizing, dividing work and planning assignments for investigation. Mastery of self-talk, satisfying curiosity, becoming more 
competent by reading other sources. Extrinsic self-talk, trying our best to convince ourselves to continue learning when working on worksheets. Relative ability self-talk, performing better efforts and presenting the results of the investigation. Relevance enhancement, students' efforts to increase the meaningfulness of tasks in life by analyzing the results of worksheets that have been done. Self-consequating, using verbal reward and punishment as a form of consequences through praises or additional scores given to motivate. Effort regulation, regulating the efforts to solve the problems investigated, and help-seeking, receiving assistance from friends in groups or lecturers when they encounter difficulties in understanding the learning material.

\section{The Aim of the Study}

The aim of this research is: (1) to determine the difference in the improvement of students' self-regulation skills before and after the implementation of the GITTW learning strategy; and (2) describe students' perception of the skills of self-regulation before and after the implementation of the GITTW learning strategy.

\section{METHOD}

\section{Model of Research}

This research is a pre-experimental research with a one-group pretest-posttest design. The design of this research consisted of one experimental group, and there was no control group. The experimental group was observed and measured before and after the treatment was given (Fraenkel and Wallen, 2009). The purpose of this research was to: (1) find the differences in the improvement of students' self-regulation skills before and after the implementation of the GITTW learning strategy; and (2) describe students' perception of the skills of self-regulation before and after the implementation of the GITTW learning strategy. The independent variable was the implementation of the GITTW learning strategy, while the dependent variable was students' self-regulation skills. The population of this research was made up entirely of students in the sixth semester of the Biology Education study program who programmed Physiology Anatomy of the Human Body in the 2017/2018 academic year. The total number of the study population was 20 students consisting of one class. The sample small is $\leq 30$ (Walpole et al., 2011). The experimental groups were observed and measured before and after the treatment was given (Fraenkel \& Wallen, 2009). The research sample was the total population. The treatment was the implementation of the GITTW learning strategy, which was carried out over three meetings, where the previous three meetings used a multimethod learning.

Students' self-regulation skills were measured by using essay and inventory tests. The self-regulation skills test in the form of essays was developed according to Bloom's taxonomy level revised by Anderson and Krathwohl (2001). A succinct discussion of the revisions to Bloom's classic cognitive taxonomy by Anderson and Krathwohl and how to use them effectively. This test was used to measure students' self-regulation skills. The self-regulation skills which analyzed in this research was (1) measured by essay test which is integrated with concept understanding and consist of sevent question about Human Anatomy and Physiology. The self-regulation skill rubric used a metacognitive 
skill rubric, because metacognitive skills are one of the components of self-regulation. The rubric was adapted from Corebima (2008). The components in the rubric gave a metacognitive skills score to the subject's answers, namely: (a) answers using their own sentences, (b) answers that are in a good order, coherent, systematic and logical; (c) grammar or language, which mean as answer letter perform by theirself with systematic, logic, and proper language; (d) reasons (analysis/evaluation/creation); (e) correct/less correct/incorrect/empty answers.

The questionnaire was used to determine students' perceptions regarding self-regulation skills used inventory Metacognitive Skills (MSI) which is adapted from MAI (Schraw \& Dennison, 1994) dan SEMLI-S (Thomas, dkk, 2008). The inventories consist of 34 items which is divided into skills for plannig, monitoring, evaluation, and revising.

The essay and inventory test instruments were given before (pretest) and after (posttest) the implementation of the GITTW learning strategy. The essay test instrument had been validated, namely with expert validation and empirical validation. The empirical validation obtained a validity test score in the range of $0.48-0.83$, which indicated that the test was valid, and the reliability test score was 0.84 (high reliability), which meant that the test was of good quality. The results of the expert validation were: Lesson Plan 3.49 (valid), Course Outline 3.45 (valid) and Student Worksheet 3.38 (valid) (Listiana \& Suharti, 2017).

\section{Data Collection and Analysis}

The data collection technique in this research involved tests and inventory methods. The research data were the scores of self-regulation skills from the students' answers on the essay test and inventory scores of self-regulation skills. The data of the results of the essay test and the self-regulation inventory were collected at the pretest and posttest. After that, the data of the results of the essay test were analyzed using the N-gain test.

The improvement of students' self-regulation skills after the implementation of the GITTW learning strategy in the Anatomy and Physiology of the Human Body subject can be analyzed through the normalized gain score $(\mathrm{g})$ with the following formula.

Gain Test:

$$
g=\frac{S_{\text {post }}-S_{\text {pre }}}{S_{\text {maks }}-S_{\text {pre }}}
$$

Description:

$$
\begin{array}{lll}
S_{\text {Pre }} & : & \text { Pretest score } \\
S_{\text {postscore }} & : & \text { Posttest score } \\
S_{\max } & : & \text { Maximum Score }
\end{array}
$$

After that the gain score was compared to the category according to Kern, et al. (2016). 
Gain index category:

$\begin{array}{lll}\text { High } & : & g>0.7 \\ \text { Medium } & : & 0.3<g \leq 0.7\end{array}$

The percentage response results were then compared with the criteria as Table 1.

Table 1

Criteria for Percentage Responses

\begin{tabular}{ll}
\hline Percentage & Description \\
\hline Figures $0 \%-20 \%$ & Very Weak \\
Figures $21 \%-40 \%$ & Weak \\
Figures $41 \%-60 \%$ & Sufficient \\
Figures $61 \%-80 \%$ & Strong \\
Figures $81 \%-100 \%$ & Very Strong \\
\hline
\end{tabular}

Source: Arikunto, 2010; Leventhal, et al., 2016

The inventory of self-regulation skills was arranged based on three aspects, namely metacognition, motivation and behavior with each indicator. Based on the data of the inventory results, the percentage of self-regulation skills responses was processed and calculated. The data of the inventory results were analyzed descriptively to calculate the percentage of self-regulation skills in questionnaires before and after the implementation of the GITTW learning strategy. Respondents answered using a closed answer scale ranging from 3 (yes) through 2 (doubtful) and to 1 (no). The answer scale was classified into a positive statement score and a negative statement score.

The inventory was calculated using the following formula:

$$
\% \text { response }=\frac{\text { student answer score } x 100 \%}{\text { maximum score }}
$$

\section{FINDINGS}

The research data of average gain scores and $\mathrm{N}$-gain of self-regulation skills are presented in Table 2 below.

Table 2

Differences in Average Gain Score and N-gain of Self-Regulation Skills

\begin{tabular}{lllll}
\hline & Pretest & Posttest & Gain & N-gain \\
\hline Score & 724 & 1480 & 756 & 12.02 \\
Average & 36.2 & 74 & 37.8 & 0.60 \\
Variance & 84.48 & 176.05 & 117.23 & 0.03 \\
SD & 9.19 & 13.27 & 10.83 & 0.17 \\
\hline
\end{tabular}


Table 3

Categories of Inventory Results of Students' Self-Regulation Skills based on Inventory

\begin{tabular}{llllll}
\hline \multirow{2}{*}{ Aspect } & Indicator & $\begin{array}{l}\text { Inventory Score } \\
\text { Before }\end{array}$ & Category & $\begin{array}{l}\text { Inventory Score } \\
\text { After }\end{array}$ & Category \\
\hline \multirow{2}{*}{ Metacognition } & Rehearsal & 60.00 & Strong & 61.67 & Strong \\
& Elaboration & 88.33 & Very strong & 93.33 & Very strong \\
& Organizing & 60.00 & Strong & 61.67 & strong \\
\hline \multirow{2}{*}{ Motivation } & Self-talk mastery & 85.33 & Very strong & 91.67 & Very strong \\
& Extrinsic self-talk & 96.67 & Very strong & 98.33 & Very strong \\
& Relative ability & 61.67 & Strong & 65.00 & Strong \\
& Self-talk & 63.67 & Strong & 65.00 & Strong \\
& Relevance & Strong & 76.67 & Strong \\
\hline Behavior & Self-consequating & 76.67 & Very strong & 96.67 & Very strong \\
& Effort regulation & 90.00 & Very strong & 90.00 & Very strong \\
\hline Average & Help-seeking & 83.33 & Strong & 80.00 & Strong \\
\hline
\end{tabular}

The Table 2 shows that the average gain is 37.8 and the average $\mathrm{N}$-gain 0.60 in the medium category and variance 0.03 . Eleven students obtained $\mathrm{N}$-gain scores in the high category, seven students obtained $\mathrm{N}$-gain scores in the medium category and two students obtained $\mathrm{N}$-gain scores in the low category. This shows that there is an increase in the students' self-regulation skills after the implementation of the GITTW learning strategy. These results show that the GITTW strategy is effective in improving students' self-regulation skills. The students' self-regulation skills data using inventory were given before and after the implementation of the GITTW learning strategy. The results are presented in Table 3.

Table 3 shows that the self-regulation skills before the implementation of the GITTW learning strategy reached $76.57 \%$ and were included in the strong category. The selfregulation skills after the implementation of the GITTW learning strategy reached $80.00 \%$ and were included in the strong category. It can be concluded that the overall responses of students related to self-regulation skills in the implementation of the GITTW learning strategy were very good.

\section{DISCUSSION}

The results of this research showed that there was an increase in the students' selfregulation skills after the implementation of the GITTW learning strategy. This can be seen from the average pretest score of 36.2, the average posttest score of 74 , the average gain score of 37.8 and the average $\mathrm{N}$-gain score of 0.60 , which is included in the medium category. Self-regulation is a process of regulating ourselves, directing ourselves in learning, and regulating learning strategies and managing our own thoughts (Kizilcec et al., 2017). It is important to develop self-regulation in learning because selfregulation skills will build the student learning process as a self-directed process (Medina et al., 2017). With self-regulation skills, learning ability will increase, which has an effect on the improvement of academic achievement. This is in line with Bandura (in Miller, 2000) that self-regulation is related to motivation and learning achievement. Self-regulation also builds up students' learning skills, so that it creates independent 
learners. This is supported by Burroughs (2017); Chuang (2019); Zimmerman (2002), who states that self-regulation is capable of developing lifelong learning skills.

According to Ramdass and Zimmerman (2011), it is very important to develop selfregulation skills in order to achieve academic goals. Another reason for the importance to empower self-regulated skills in learning process is that the extent to which learners are capable of regulating their own learning greatly enhances their learning outcomes (Persico \& Steffens, 2017). Students who have self-regulation skills will become independent in learning by setting goals, choosing and using the best strategies, monitoring their performance and continually reflecting their learning results over a long period of time (Chuang 2019; Zimmerman, 2008). Self-regulation skills also include time management, planning and managing strategies, and perseverance in completing difficult tasks. Thus, it can be concluded that self-regulation is a proactive process in which students organize and manage their thinking and behavior to achieve satisfying results.

The results of this research also show that the potential of the GITTW learning strategy is quite high for improving students' self-regulation skills. This is supported by the research by Listiana and Suharti (2017), which indicated that the learning media using the GITTW learning strategy have a high level of practicality $(88.25 \%)$. The learning media have the potential to empower self-regulation skills. The GITTW learning strategy, which is packaged in the form of a cooperative learning model, is an innovative strategy that integrates students' thinking, writing and communication skills to investigate problems. The self-regulation skills can be developed through the GITTW learning strategy whose learning stages encourage students to practice gradually to become independent learners.

The syntax of the GITTW strategy that has the potential to develop self-regulation skills is as follows. First, identifying topics, grouping and determining subtopics (integrated Think, Write). At this stage students organize groups to work on determining subtopics. The learning process is improved by managing thoughts and writing the results of the discussion as the beginning of group work. Second, planning the tasks that will be studied and compiling the results of the discussion (integrated Think, Talk and Write). At this stage, students organize their ways of thinking to plan tasks, manage time and determine learning strategies. In addition, the group arranges time to share ideas with other groups related to task planning. Third, investigating, observing, collecting and writing information (integrated Think and Write). At this stage, each individual in the group organizes the strategy by sharing the investigation tasks, and gathering information to solve problems. Fourth, analyzing, discussing and synthesizing information (integrated Think, Talk and Write). At this stage, the emphasis is mainly on thinking skills in analyzing information obtained, and sharing in groups for presentation (Modified by Listiana from Sharan \& Sharan 1992 and Huinker \& Laughin,1996). Fifth, students present the final results and have a class discussion (integrated Think and Talk). At this stage, the students are trained to organize their thoughts and emotions as well as strategies in answering questions in a class discussion. Sixth, evaluating, reflecting and concluding (integrated Think, Talk and Write). At this stage, students 
learn to organize, monitor, control and assess the performance of their own groups. Thus, during the learning process of the GITTW learning strategy, all of the above activities can clearly empower students to become self-regulated learners.

Through the GITTW syntax, self-regulation skills can be developed and trained gradually during the learning process. The GITTW learning strategy can improve selfregulation skills because every stage of the GITTW syntax shows independent habits. The GITTW strategy has the potential to shape students into independent learners. This is in line with Bahri and Idris (2018) opinion that self-regulated learners can be empowered or trained through specific strategies. The previous research also reveals that self-regulation skills could also be developed through homework activities (Ramdass \& Zimmerman, 2011; Persico \& Steffens, 2017).

The importance to empower self-regulated skills in learning process is that the extent to which learners are capable of regulating their own learning greatly enhances their learning outcomes (Persico \& Steffens, 2017). Students who have self-regulation skills will become independent in learning by setting goals, choosing and using the best strategies, monitoring their performance and continually reflecting their learning results over a long period of time (Chuang 2019; Zimmerman, 2008). Self-regulation skills also include time management, planning and managing strategies, and perseverance in completing difficult tasks. Thus, it can be concluded that self-regulation is a proactive process in which students organize and manage their thinking and behavior to achieve satisfying results. Through the GITTW syntax, self-regulation skills can be developed and trained gradually during the learning process. The GITTW learning strategy can improve self-regulation skills because every stage of the GITTW syntax shows independent habits. This is relevant with theoretical background. then it can be concluded The GITTW strategy has the potential to shape students into independent learners.

The results of the analysis show that the average inventory of self-regulation skills before the implementation of the GITTW learning strategy reached $76.57 \%$ and was included in the strong category, while the average inventory of self-regulation skills after the implementation of the GITTW strategy reached $80 \%$ and was included in the very strong category. The students' self-regulation skills experienced an increase. This was proven by the inventory results after the learning, which is included in the very strong category. This strong increase is due to the implementation of the GITTW learning strategy for three meetings that had been able to encourage and empower students' abilities in managing their learning, thinking and time, and monitoring their learning to achieve satisfying goals. The habit of empowering these learning activities in learning by using the GITTW strategy for a long period of time will be able to shape students into independent learners.

\section{CONCLUSION}

Based on the results and discussion of this research, it can be concluded that there are improvements in students' self-regulation skills after the application of the GITTW strategy in Physiology Anatomy of the Human Body courses. Also, the students' 
perception of self-regulation skills before the implementation of GITTW belongs to the good category and the students' perception of self-regulation skills after the implementation of GITTW belongs to the very good category.

This research was limited to the Human Physiology Anatomy, Biology Education study program in universities. This will be more challenging and interesting when applied in senior high schools or junior high schools. Future researchers can conduct similar research in relation to cognitive abilities and students' character development.

\section{ACKNOWLEDGEMENT}

The authors would like to thank Ministry of Research, Technology and Education of the Republic Indonesia, who gave grant for this research.

\section{REFERENCES}

Akcay, N. O., \& Doymus, K. (2012). The effect of GI and cooperative learning techniques applied in teaching force and motion subjects on students academic achievements. Journal of Educational E-Journal, 2(1), 109-123.

Ansari, B. I. (2004). Implementasi model pembelajaran think talk write (TTW) terhadap pemahaman dan komunikasi matematika [Implementation of the think talk write (TTW) learning model for mathematical understanding and communication] (Unpublished doctoral dissertation). Bandung, Indonesia: Universitas Pendidikan Indonesia.

Arikunto, S. (2010). Prosedur Penelitian [Research procedure]. Jakarta: Rineka Cipta.

Bahri, A., \& Idris, I. S. (2018). Development and validation of learning strategy for metacognitive skills empowerment: PBLRQA (PBL integrated with reading, questioning, and answering). Journal of Physics: Conference Series, 1028, 1-8.

Bandura, A. (1993). Perceived self-efficacy in cognitive development and functioning. Educational Psychologist, 28(2), 117-148.

Bannert, M., Sonnenberg, C., Mengelkamp, C., \& Pieger, E. (2015). Short- and longterm effects of students' self-directed metacognitive prompts on navigation behavior and learning performance. Computers in Human Behavior, 52, 293-306.

Boekaerts, M. (1996). Self-regulated learning at the junction of cognition and motivation. European Psychologist, 1(2), 100-112.

Burroughs, M. D., \& Barkauskas, N. J. (2017). Educating the whole child: socialemotional learning and ethics education. Ethics and Education, 12(2), 218-232.

Cen, L., Ruta, D., Powell, L., Hirsch, B., \& Ng, J. (2016). Quantitative approach to collaborative learning: performance prediction, individual assessment, and group composition. International Journal of Computer-Supported Collaborative Learning, 11(2), 187-225. 
Chen, C. S. (2000). Self-regulated learning strategies and achievement in an introduction to information systems courses. Retrieved from http://www.asra.org/jtlp/chenspring2002.pdf.

Chuang, S. (2019). Exploring women-only training program for gender equality and women's continuous professional development in the workplace. Higher Education, Skills and Work-Based Learning, 9(3), 359-373.

Corebima, A. D. (2008). Rubrik keterampilan metakognisi yang terintegrasi dengan tes essay [The metacognition skills rubric that is integrated with the essay test]. Malang: Rubrik MAD. DePorter, B. 1992. Quantum Learning. Bandung: Penerbit Kaifa.

Fraenkel, J. R., \& Wallen, N. E. (2009). How to design and evaluate research in education. New York, NY: McGraw Hill Companies.

Hosseini, F., Maktabi, G. H., Yailagh, M. S., \& Yakhchali, A. H. (2018). The effects of teaching reflective thinking model on academic self-efficacy, achievement motivation, intention certainty and reflective thinking of the of Farhangyan University students in Ahvaz. Ahvaz, Iran. Amazonia Investiga, 7(13), 401-418.

Huinker, D., \& Laughlin, C. (1996). Talk you way into writing. In. P. C. Elliot, \& M. J. Kenney (Eds), Communication in mathematics K-12 and beyond. Year book of the national council of teachers of mathematics (pp.81-88). Reston, VA: National Council of Teachers of Mathematics.

Ifenthaler, D. (2012). Determining the effectiveness of prompts for self-regulated learning in problem solving scenarios. Journal of Educational Technology \& Society, 15(1), 38-52.

Kizilcec, R. F., Perez-Sanagustin, M., \& Maldonado, J. J. (2017). Self-regulated learning strategies predict learner behavior and goal attainment in Massive Open Online Courses. Computers \& Education, 104, 18-33.

Listiana, L., \& Suharti, P. (2017) Development and validation of learning tools GITTW strategy to empower self-regulation skills. Proceeding of the 1st International Conference on Mathematics, Science and Education, Graha Cakrawala Universitas Negeri Malang, Indonesia.

Listiana, L., Susilo, H., Suwono, H., \& Suarsini, E., (2016). Contributions of metacognitive skills toward students' cognitive abilities of biology through the implementation of GITTW (Group Investigation combined with Think Talk Write) strategy. Proceeding of International Conference on Teacher Training and Education Sebelas Maret University, Vol 1, Nomor 1, hal: 411-418, Januari 2016. Online Journal of Fakulty of Teacher and Training Education Sebelas Maret University, SurakartaIndonesia. Retrieved from http://jurnal.fkip.uns.ac.id/ index.php/ ictte/article/View/7638

Listiana, H. Susilo, H. Suwono, \& E. Suarsini. (2016). Empowering students' metacognitive skills through new teaching strategy (Group investigation integrated wiyh 
think talk write) in biology classroom. Journal of Baltic Science Education, 15(3), 391400 .

Listiana, L. (2013). Pemberdayaan Keterampilan Berpikir dalam Pembelajaran Biologi melalui Model Kooperatif Tipe GI (Group Investigation) dan TTW (Think Talk Write) [Empowerment of Thinking Skills in Biology Learning through the Cooperative Model Type GI (Group Investigation) and TTW (Think Talk Write). Prosiding Seminar Nasional X Biologi, Sains, Lingkungan dan Pembelajarannya. Surakarta 6 Juli 2013. Volume 1. ISBN: 978-062-8580-94-6 Surakarta: FKIP UNS. Livingston, J. 1997. Metacognition: An overview. Retrieved (Online) (http://www.gse.buffalo.edu/fas/shuell/cep564/metacog.htm)

Medina, M. S., Castleberry, A. N. \& Persky, A. M. (2017). Strategies for improving learner metacognition in health professional education. American Journal of Pharmaceutical Education, 81(4), 1-14.

Mitchell, M. G., Hilary, M., Holder, M., \& Stuart, D. (2008). Group investigation as a cooperative learning strategy: An integrated analysis of the literature. The Alberta Journal of Educational Research, 54(4), 388-395.

Ozsoy, G., \& Ataman, A. (2009). The effect of metacognitive strategy training on mathematical problem-solving achievement. International Electronic Journal of Elementary Education, 1(2), 67-82.

Persico, D., \& Steffens, K. (2017). Self-regulated learning in technology enhanced learning environments. Technology Enhanced Learning, 1, 115-126.

Pintrich, P. R. (2000). The role of goal orientation in self-regulated learning. In M. Boekaerts, P. R. Pintrich, \& M. Zeidner (Eds.), Handbook of self-regulation (pp.451502). San Diego, CA: Academic Press.

Psycharis, S., \& Kallia, M. (2017). The effects of computer programming on high school students' reasoning skills and mathematical self-efficacy and problem solving. Instructional Science, 45(5), 583-602.

Rivard, L. P., \& Straw, S. B. (2000). The effect of talk and writing on learning science: An exploratory study. Science Education, 84(5), 566-593.

Schraw, G., \& Dennison, R. S. (1994). Assessing metacognitive awareness. Contemporary Educational Psychology, 19, 460-475

Sharan, Y., \& Sharan, S. (1992). Expanding cooperative learning through group investigation. New York, NY: Teachers College Press.

Sihombing, R. B., Solihatin, E., \& Sudrajat, A. (2018). The effect of cooperative learning models and self-efficacy to critical thinking ability on social studies. International Journal of Advances in Scientific Research and Engineering, 4(7), 89-96.

Slavin, R. E. (2008). Educational psychology: Theory and practice. Boston: Pearson Education. 
Slavin, R. E. (1994). Educational psychology: Theory and practice. Toronto. Allyn and Bacon.

Sungur, S., \& Tekkaya, C. (2006). Effects of problem-based learning and traditional instruction on self-regulated learning. The J. of Educational Research, 99(5), 307-320.

Susantini, E., Sumitro, S. B., Corebima, A. D., \& Susilo, H. (2018). Improving learning process in genetics classroom by using metacognitive strategy. Asia Pacific Education Review. 19(3), 401-411.

Tanriseven, I. (2014). A tool that can be effective in the self-regulated learning of preservice teachers: The mind map. Australian Journal of Teacher Education, 39(1), 6580 .

Thomas, G., Anderson, D., \& Nashon, S. (2008). Development of an instrument designed to investigate elements of science students" metacognition, self-efficacy and learning processes: The SEMLI-S. International Journal of Science Education, 30, (13), 1701-1724.

Tsoi, M. F., Goh, N. K., \& Chia, L. S. (2004). Using group investigation for chemistry in teacher education. Asia Pacific Forum on Science Learning \& Teaching, 5(1), 6.

Walpole, R. E., \& Myers, R. H. (1995). Ilmu Peluang dan Statistika untuk Insinyur dan Ilmuwan. Edisi ke-4. [Probability and Statistic for Engineers and Scientist 4 th]. Bandung: Penerbit Institut Teknologi Bandung.

Weinstein, C. E., Husman, J., \& Dierking, D. R. (2000). Self-regulation interventions with a focus on learning strategies. In M. Boekaerts, P. R. Pintrich, \& M. Zeidner (Eds.), Handbook of self-regulation (p. 727-747). Academic Press.

Woolfolk, A. E. (1987). Educational psychology. Englewood, Cliffs, NJ: Prentice-Hall.

Zimmerman, B. J. (1989). A social cognitive view of self-regulated academic learning. Journal of Educational Psychology, 81(3), 329-339.

Zimmerman, B. J. (1990). Self-regulated learning and academic achievement: An overview. Educational Psychologist, 25(1), 3-17.

Zimmerman, B. J. (2008). Investigating self-regulation and motivation: Historical background, methodological developments, and future prospects. American Educational Research Journal, 45(1), 166-183.

Zimmermann, B. J. (2002). Becoming a self-regulated learner: An overview. Theory into Practice, 41(2), 64-70.

Zubaidah, S., Corebima, A. D., Mahanal, S., \& Mistianah. (2018). Revealing the relationship between reading interest and critical thinking skills through remap GI and remap jigsaw. International Journal of Instruction, 11(2), 41-56. 